\title{
LEONE DE SOMNI AND THE ARCHAEOLOGY OF THE DIRECTOR'S WORKBOOK
}

Leone De Sommi is well known to scholars of the theatre as a leading figure of theatrical activity in Mantua in the late 1500s'. De Sommi wrote plays ${ }^{2}$,designed settings and costumes,stage-manged, and directed a variety of theatrical entertainments - ballets, musicals, intermezzi, comedies. tragedies and pastorals - at the Gonzaga court in Mnatua between 1556 and 1592. He directed outside of Mantua,in the Duchies of Savoy and Turin, and. between 1538 and 1556, at the Este court in Ferrara. where he played an active role (as a director, dramaturge, and choreographer) in the early staging experiments of Giambattista Guarini's Il pastor ficlo.

Most historians of the theatre claim the director emergect as an independent professional towards the end of the nineteenth century. The Duke of Saxe-Meiningen (1826-1914) is generally cited as the first modern regissem (Cole and Chinoy 22). The accepted view is that the rise of naturalism and the new dramas of realism (embodied in works such as Zola's Therese Raquir, Checkhov's The Chery Orchard and Gorky's The Lower Depths) demanded an ensemble interpretation with an emphasis on scenic realism. Thus the appearance of the modern director - a commanding visionary in control of every aspect of production, who could visualize, interpret, harmonize all the elements of the scenic environment and express the "soul" of the play (Cole and Chinoy 25).

The general assumption of most theatre historians is that prior to the $1850 \mathrm{~s}$ or so the director is a shadowy, underdeveloped figure rather than a professional functionary. Impromptn at Versailles(1663)and Hamlet (1601)are cited as seminal but embryonic considerations of the director's craft. Both Moliere and Shakespeare figure prominently as director-authors but with the emphasis on their activities as atuthors, while the medieval stage manager is usually regarded as no more than a precursor of the director. In fact, according to standard theatre sources, there were no ctirectors, in the full sense of the term, till the end of the nineteenth century.

Leone De Sommi is generally described as a foremunner or embryonic 
director (Cole and Chinoy 16); however, a careful examination of his Quattro Dialoghi in materia di rappresentazioni scentiche. completed in 15663 , shows that De Sommi functioned as a clirector in the modern sense of the word. Theatre historian Cesare Molinari observes that in the fifteenth and sixteenth centuries there were no real experts in the theatre, except for De Sommi, who devoted himself almost exclusively to the study and practice of theatre (125). The Quattro dialoghi were written principally as a manual of practical instruction for other theatre professionals rather than as abstract theory for scholars and playwrights. This work, my research shows, is the first systematic account of the art of the director in western theatre.

Quattro dialoghi consists of four dialogues between a fictional director called Veridico ${ }^{4}$ and two noblemen, Santino and Massimiano, in which De Sommi deals with the following eight topics: how to choose a play, choose the actors, work with actors, costume a show, set a stage, work with lights, stage pastorals and integrate intermezzi, and unify production through the harmonization of actors, lights and other elements: "...che tutta insieme sia poi un corpo bene organizzato et unito, non sensa polsi ne senza spirito."5 Unity of impression is achieved through calculation and vigorous testing in rehearsal. Thus De Sommi's methodology involves the interpretation of abstract impressions evoked by the initial reading of the play-text and their transformation into concrete images on stage. A comparison between De Sommi's method and Jacque Copeau's definition of the directorial process in his essay, Dramatic Economy, reveals these directors have much in common:

Directing is the sum total of artistic and technical operations which enables the play as conceived by the author to pass from the abstract, latent state, that of the written script, to concrete and actual life on the stage (Cole and Chinoy 214).

De Sommi's ideal director has vision, imagination, and a plan of action, which are recorded in a workbook.

The type of workbook De Sommi has in mind is known to modern scholars and theatre practitioners as the director's workbook or production plan, or in some cases as the director's private notebook. Theatre historians, geneally speaking, regard the director's workbook as the most significant point of access to the directorial process and to the aesthetics of production. A number of seminal workbooks by pioneering directors are compiled in Directors on Directing (1963), a standard source book of the modern theatre, including Stanislavski's Production Plan for the 1902 production of The 
Louer Depths at the Moscow Art Theatre, Brecht's Notes for the 19.49 production of Mother Combage in Berlin, and Elia Kazan's Privalte Notehook for the 1947 New York production of A Streetcar Named Desire (Cole and Chinoy 281-95, 333-46,36-7-9). De Sommi advocated the use of a clirector's plan in 1566. This fact by itsell suggests there was a critical shift in the art of the theatre at that time, and in the status and function of the director.

The purpose of this paper is to analyze De Sommi's comments on the icleat of a director's plan, and to illustrate that this innovation, thus far overlookecl by theatre historians, embodies a directorial practice which is not significantly different from its correlative in modern theatre.

In Part Three of Quattro dialogbi Veridico describes the director's plan or guicle ["guida"] as a useful and necessary organizational tool of production (Quattro dialoghi, Dialogue Three: 54). Veridico is caught in the act of preparing his workbook by interlocutors Santino and Massimiano, who have arrived ahead of the pre-scheduled time for the master's discussion on how to direct a play. Veridico's workbook, which organizes and documents the director's vision and method of constructing a theatrical production, inchudes the following constituent parts: a property chart, a costume plot, a scene breakdown, and a character entrance and cue line chart (Quattro clialoghi. Dialogue Three: 54). The property chart lists the stage properties required by each character in every scene as well as their locations backstage, and gives directions for moving the actors on and off the stage. Veridico emphasizes the importance of accurate and detailed notations for each character and every property and observes that a missing property maty throw the show off: "...puo in gran parte sconcertare lo spettacolo". In the English translation by Allardyce Nicoll this reads: "...to forget even some small article may put the players very much out" (Quattro dialogbi. Dialogue Three: 54; Nicholl 256). The difference hetween players and show is significant. A missing stage property could throw an actor "off" and out of the action, and at the same time the rhythm of the entire scene, thereby shattering the illusion of the stage impression. Verisimilitude was the primary measure of excellence in production in this period and Veridico's pictorial stage presupposes detail. To shatter the illusion with a missing stage property, a hurried entrance, an actor crossing from stage left to right rather than right to left presents potential problems for the sixteenth-century director. Scenic details reflect deliberate and premeditated choices on the part of the director, who calculates an impression of reality via a perfection of artifice.

veridico organizes and itemizes costumes for each character on a master costume list. Actors are generally assigned only one costume apiece: how- 
ever, variations in colour, cut and accessories provide scenic contrast (Quattro dialoghi, Dialogue Three: 49). The costume list serves to prevent confusion among the actors in identifying and locating their costume pieces and personal accessories before and during the performance. Veridico is aware that actors must be comfortable inhabiting their costumes well in advance of the final performance, and he makes provision for this by testing the costumes in technical rehearsals (Quattro dialoghi, Dialogue Three: 52). When costumes are finally approved, they are entered onto the master costume list.

The scene breakdown lists all the scenes of the play accompanied by a list of the characters that appear on stage in chronological playing order. The character entrance and cue line chart indicates the place the character enters from (Serlio's house or street), the cue line which prompts the character's entrance, and the first words or the line that each character utters on entering the scene(Quattro dialoghi. Dialogue Three: 54). This detailed listing would help organize the actors backstage, and facilitate smooth transitions between scenes. Furthermore, this tool of organization would prevent gaps between scenes, which could interrupt the established momentum of the dramatic action (Quattro dialoghi, Dialogue Three: 39).

Cues for lighting and special effects, also included in the clirector's plan, would be tried and tested in technical rehearsals well in advance of the performance. Veridico's concern is that nothing - not the smallest detail of lighting, costuming, make-up, decor — is left to chance. Every moment of the performance is deliberately calculated by the director to create and maintain scenic illusion.

From Veridico's clescription of the first rehearsal in Dialogue Three, we can determine that his plan would have included icleas with respect to the interpretation of the play and of specific roles. Vericlico casts prior to the first reading of the play, choosing the actors who seem "fittest" for the various roles (Quattro dialoghi, Dialogue Three: 39). Veridico believes it is more important to have good actors than a good play (Quattro dialoghi. Dialogue Three: 39). His ideal in acting calls for harmony between ancient and contemporary approaches (Molinari 137). Casting to type is balanced with the individual actor's (rocal and physical) suitability to the role. The actor must embody the essential nature of the character he has to interpret ["la qualita del personagio che hanno da imitare"] (Quattro dialoghi. Dialogue Three: 39). At the "first reading", the entire cast is brought together to read the play out loud from stant to finish so the actors maly be instructed in its subject matter, and by this De sommi presumably means the theme of the play and 
his vision of its realization. This initial encounter with the text is followed by a thorough discussion on characterization, led by Veridico, who impresses in the minds of all the nature of the character that they hale to imitate. Veridico then dismisses the actors, giving them time to "Jearn their parts" ["imparar le parti loro"] hefore the following rehearsal".

In contemporary theatre practice the type of plan described by I)e Sommi is sometimes found in two forms: the promptbook, usually in the care of the stage manager, who records directions into the hook and prompts when necessary, and the personal workbook, such as Elia Kitzan's notes for $A$ Streetcar Named Desire. Both the promptbook and the personal workbook embody the two phases of the director's work: the staging of the play cluring the rehearsal period and the director's private work of analysis and imagination before the rehearsal period begins. In De Sommi the kinds of materials we would find in both prompthook and workbook are not distinguished, but together they form what he describes as a director's list or guide ["una lista", "guida"] (Quattro dialoghi, Dialogue Three: 54).

Historical precedents for the promptbook are found in the theatre of the Middle Ages, where the clerical master of ceremonies would supervise the execution of the passion plays based on the directions in the promptbooks. The image of the medieval regissenr has survired in Jean Fouquet's miniature of Mystere de Sainte-Apolline (1460). Here the maitre de jeu conducts the performance among the players from directions in the prompthook, with a conductor's baton in hand. In Hubert Cailleau's miniature of the stage director of Valenciennes (1547) and Jakoh Rufs lon des Herren Ireingarten (1539), promptbook and conductor's baton figure prominently. In the extant Liw re de Conduite du regissenr we find a thorough account of the organization and production of the 1501 Mystere de la Passion in Mons. This promptbook embodies the work of two conducteurs des secrets, though the whole town collaborated in this lavish eight-day, amateur production involving months of preparation and over three-hundred amateur actors (Nagler 4953). From sixteenth-century Italy, we have directorial notes in letter form dated November 10,1560. On the staging of comedy and on comic characterization by Alessandro Piccolomini ${ }^{7}$ a theorist and playwright associated with the Accademia degli Intronati of Siena.

Extant written and pictorial evidence indicates that the medieval maitre cle jen moved about the stage in full riew of the audience using the promptbook as production guide. The promptbook represents, in part, a record of the performance. With De Sommi the regissem\% is no longer in view of the audience, and this suggests that the role and function of the director hats 
shifted dramatically.

In Quattro dialoghi we encounter an artistic leader and guide who wields considerable authority over cast and crew. He scheclules, calls and conducts rehearsals with actors. He has the authority to bar visitors from the rehearsal hall ${ }^{8}$. He oversees designers and technical crew. In Dialogue Four we find Veridico seated in the house [auditorium] so he can view the full effect of the scenic perspectives as he orders his assistants to light lamps and reliefs in preparation for a technical rehearsal (Quattro dialoghi, Dialogue Four: 54). Veridico's methodology posits an artistic hierarchy and strict adherence to a single point of view, a personal vision committed to paper and embodied in a workbook or director's plan.

The principal scholarly value of the workbook consists in the fact that it allows us to determine what an individual director chooses to emphasize, and the extent to which the entries reflect what took place in rehearsals and performance. While there are no surviving workbooks for De Sommi's productions, existing documentation and Quattro dialogbi suggest De Sommi was a master of pre-production planning and organization in all aspects of production from idea to realization.

The director's function begins with the selection of the play for representation. Vision, De Sommi believes, derives from the director's initial response to the play's basic shape and story, and so Veridico endeavors to choose a play that satisfies him ["che mi satisfacesse"]. A play is perfect when omitting the smallest part renders it imperfect. A satisfactory play is written in good prose style. Choosing the right play requires knowledge of the audience, its taste and expectations, as well as some knowledge of dramatic theory. Veridico privileges new plays or at least plays that are little known, since he regards novelty as attractive in a theatrical production (Quattro dialogbi. Dialogue Three: 38). Veridico provides a cautionary note regarding the innate power of theatre to "move" the spectator. Thus a satisfactory play rewards virtues which are to be imitated and punishes vices which are to be avoided and condemned ("A' lettori," in Quallro dialoghi 7). A play must be useful, pleasurable and achere to ideals of propriety and verisimilitude with respect to subject, character, and action (Quattro dialogbi, Dialogue One: 17-19).

With respect to genre, Veridico favours the pastoral on the grounds that it makes a much more pleasing and beautiful show (Quattro dialoghi, Dialogue Three: 53), and by this he means that the pastoral permits the writer to introduce fantastical subjects and characters, and exotic settings which, in performance, target the senses as well as the intellect of the spec- 
tator. At the same tine, De Sommi is aware of the chatlenge facing the director in producing this highly complex genre - a combination of poetry, music and clance. According to Veridico, the pastoral is, in fact, the most difficult gene to direct. He states that the degree of organization and skill required to achieve unity of production in costuming, lighting, choreography, creating a scenic environment and working with actors, dancers, choreographers, designers and technicians demands a seasoned director at the height of his creative powers:

Et, sopra tutti gl'arvertimenti, bisogna che chi essercita questi poemi sia bene essercitato, perche e molto piu difficile condur una si fatta rappresentazione che stia bene, che non e a condurre una comedia?

De Sommi's ideal ctirector, if he is not author of the play, is subordinate to the intentions of the poet and the literary text. He has the ability to visualize, analyze and interpret the visible text - words, chamatic action and character objectives. He is able to demonstrate icteas not always expressed in the text, such as character intentions and gestural stage behaviour, which are necessarily present in the invisible sub-text (Quattro dialoghi, Dialogue Three: 42. 46), and he has a grammar at his command to articulate both visible and invisible texts in concrete directions to actors, designers, and technicians. From author's soggetto to characterization and manner of costuming the director must be able to grasp, distil and physically express the poet's idea in space. The poet provides "flesh", the actor "spirit" and the director transforms flesh and spirit into a unified organic whole, integrating all the arts at his disposal (sets, costumes, colour, lights, movement) into "soul". De Sommi's director is thus soul-maker.

From page to stage this highly complex transformational process, which differentiates performance from literary text, implies a period of prepatory time, that is to say, a period of private analysis and reflection recorded in the director's workbook. The fact that the workbook is a written documentation is significant: to make sure all aspects of production have been corered and that nothing is left to chance, avoiding at all costs "the haphazard assembling of materials". As Pavis observes, the plan or mise en scene is an object of knowledge (Pavis 24). One "arrives" at representation from vision to private analysis, rehearsal, and finally to realization which, with the audience present, completes the theatrical experience.

In Directors on Directing, absolute control and personal vision seem to be the criteria and defining features of the modern theatre director, whose function includes many tasks: artistic unification, respecting and representing the 
playwright's intentions, representing the audience, guiding actors, technicians, designers, and organizing a working process in both production and pre-production phases of theatrical representation. If we accept this definition of the modern director, then De Sommi is more than a foremmner or promise of a director, as most histories of the theatre and of the art of direction would lead us to believe. While working within a tradition of sixteenthcentury rule-based classicism, De Sommi's vision and methodology is situated outside the directorial practice inherited from the late Middle Ages. His advocacy of the director's workbook alone suggests that De Sommi has more in common with modern directors such as Stanislavsky or Kazan than with the medieval stage manager - and similar comparison could be made with other aspects of his dramatic theory and instructions on acting, directing, and stagecraft.

The realistic bias of his acting method (creating an illusion of the character so that the audience does not recognize the actor); his intensive rehearsals; his psychological considerations in creating scenic mood through the use of colour and lights; his emphasis on the ensemble rather than the star-system; his artistic hierarchy, with the clirector as guide and autocrat; his advocacy of a directing method embodied in a workbook; and finally, the professionalism he brought to every aspect of theatrical production - all these things reflect the ideas of a pioneer director whose work in the sixteenth century already has all the fundamental characteristics of the work of a modern professional.

Acadia Lniversity'

\section{NOTES}

I Biographical information on De Sommi (1527-1592) may be found in Alessandro D'Ancona, Le origine del teatro italiano.

2 De Sommi's literary output, in both Hebrew and Italian, was substantial; however. most of his works were destroyed in a fire at the National Lilbrary of Turin in 1904 . The collection consisted of sixteen manuscripts: four volumes of poetry, eleven of plays (six comedies, three pastorals, several intermezzi) and two volumes of poetry. Among the poetry were translations into ollata rima of forty-five Psalms accompanied by the original Helorew. The extant works include three comedies, Tre Sorelle, Il Tamburo, and Tsaboth B'dibutha dKiddusbin - the latter considered to be the first Hebrew drama; a pastoral, Hirifile; and Quatro dialoghi in materia di rappresentazioni sceniche.

3 The Introduction to Quattro dialoghi is dated 1556 but most De Sommi scholars, including D'Ancona and Marotti, believe the dialogues were composed, in part, about a decade later. Allardyce Nicoll in the introduction to his English translation of De Sommis Dialogues on Stage Affairs in The Detelopment of the Theatre states: "...though they were 
begun in that year, they were certainly not completed until at least al decale latter. The surest clues are the reference to Flaminia and to leono Aretino. Haminia made a great stir when she came to Nantuat in 156- and leono Aretino's work (sic) for Duke Gugliemo's wedding wats carried out in 1561 . One might suggest that the composition of the original manuseript wats undertaken alsout this time; it mat be that the copyist's date 1556 was put in error for 1565" (Allardyce Nicoll, The Detedopmem of the "Theatre 237).

In the clialogues, De Sommi speaks through the voice of Vericlico (which literally: means the truth-teller'). This literary style - characteristic of the period - permits De sommi to critique current theatrical practice while promoting himself and his ideas. In this regard, De Sommi's dialogues could be compared to Castiglione's The Conntier.

5 Quallro dialogbi Dialogue Two: 3I. "That together the whole is a well organized and unified body lacking neither pulse nor spirit" (C. A. Blanchard-Rothmuller 85). Nicoll translates this passage as: "the whole taking shape as a well planned organism, unified by a dominant spirit." (2.48).

${ }^{6}$ Quattro dialoghi Dialogue Three: 39. This description suggests that the director walks into the rehearsal hall with at conception of some sort in mind.

7 The letter by Piccolomini (1508-1578) may be found in Danicle Seragnoli, "Lat struttura del personaggio e della fabula nel teatro del Cinquecento" (Cruciani and Seragnoli $297-31^{-7}$ ).

8 See the opening exchange between Santino and Massimiano in Dialogue One.

9 Quaturo dialogbi Dialogue Three: 53. "He who attempts one of these pastoral shows must be a real expert, for it is much more difficult to win success in them than in comeclies." Nicoll 255.

\section{WORKS CITED}

Blanchard-Rothmuller, C. A. "Four Dialogues on Stage Representation: A Translation with Introduction and Notes," Diss., Indiana U, 1973.

Brecht, Bertolt. "Model for Mother Conrage and ber Children." Cole and Chinoy 333$+6$.

Cole, Toby, and Helen Krich Chinoy. Ecls. Directors on Directing: A Source Book of the Hodern Theatre. rev. ed. Indianapolis: Bobbs-Merrill, 1963.

Copeau, Jacques. "Dramatic Economy." Cole and Chinoy 21+-25.

Cruciani, Fabrizio, and Daniele Seragnoli, Eds. Il teatro italiano nel Rinascimento. Bologna: Il Mulino, 1987.

DAncona, Alessandro. Le origini del teatro italiano. 2 vols. Torino: Ermanno Loescher, 1891.

De Sommi, Leone. Quallro dialoghi in materia rappresentazioni sceniche, ed. Feruccio Marotti. Milan: Il Polifilo, 1968.

Kazan, Elia. "Notebook for A Streetcar named Desire." Cole and Chinoy 364-79.

Maroti, Ferruccio. "Introduzione." De Sommi xv-xxxv.

Molinari, Cesare. Theatre Through the Ages. Trans. Colin Hammer. London: Cassell. 1975.

Nagler, A. M. A Somre Book in Theatrical History. New York: Dower, 1952.

Nicoll, Allardyce. The Detelopment of the Theatre. $3^{\text {rd }}$ ed. London" George Harrap, 1927 .

Pavis, Patrice. Theatre at the Crossroads of Culture. Trans.. Loren Kruger. London: Routleclge, Chapman \& Hall, 1992.

Stanislarski, Konstantin. "Production Plan for The Lower Depths." Cole and Chinoy" 281-95. 